\title{
Design of Pilot Plant Packed Column for the Dehydration of Water from Ethanol-Water Mixtures
}

\author{
A. O. Okewale' ${ }^{1}$ P. K. Igbokwe ${ }^{2}$, K. A. Babayemi ${ }^{3}$ \\ ${ }^{1}$ Department of Chemical Engineering, Federal University of Petroleum Resources, \\ Effurun, Nigeria \\ ${ }^{2}$ Department of Chemical Engineering, Nnamdi Azikiwe University, Awka, Nigeria \\ ${ }^{3}$ Department of Chemical Engineering, Anambra State University, Uli, Nigeria \\ Email: oketunde2001@yahoo.com
}

Received 28 January 2015; accepted 20 March 2015; published 24 March 2015

Copyright (C 2015 by authors and Scientific Research Publishing Inc.

This work is licensed under the Creative Commons Attribution International License (CC BY).

http://creativecommons.org/licenses/by/4.0/

(c) (1) Open Access

\section{Abstract}

This use of biomass-based adsorbent has been explored for the column study of the adsorptive dehydration of water in ethanol-water mixtures. The column study was carried out using enzyme modified corn starch and the breakthrough curve parameters were used to design the packed bed column. The effect of flow rate on the breakthrough curves revealed that adsorption efficiency decreased with increased inflow rate. The empty bed contact time $(\tau)$ of the pilot plant packed column was $35.35 \mathrm{~min}$ while the breakthrough time is $40.78 \mathrm{~min} .66 .7 \%$ was the fraction of capacity left unused for the pilot plant from the design.

\section{Keywords}

Enzyme Modified Cornstarch, Design, Fixed Column, Breakthrough Curve, Dehydration, Ethanol-Water Mixtures

\section{Introduction}

Fixed column adsorption study can be operated in series or in parallel. There are two types of influent modes for fixed bed columns, down flow and up flow. The advantage of a down flow design is that the adsorption of organics and the filtration of suspended solids can be accomplished in a single step [1]. Although, up flow fixed bed reactors have been used, down flow beds are used more commonly to lessen the chance of accumulating particulate material on the bottom of the bed, where the particulate material would be difficult to remove by 
back washing. Small scale column tests can be employed to simulate the potential performance of the adsorbent and the results obtained extrapolated in the design of full-scale reactors [2]. Under continuous influent flow, the equilibrium adsorption zone moves downward through the bed. As the equilibrium zone approaches the bottom of the column bed, the concentration of adsorbate in the effluent increases, and finally equals the influent adsorbate concentration. From this, the concept of breakthrough can be defined as the amount of influent solution passing through the bed before a maximum effluent concentration is reached [3] [4]. Breakthrough and exhaustion are defined as the phenomena when the ratios of effluent-to-influent concentrations are $5 \%$ and $95 \%$ respectively [4]. Values of column breakthrough and exhaustion are often used to evaluate adsorption parameters in column adsorption systems. Packed column can be designed using two approaches, scale-up procedure and kinetic approach. In both approaches a breakthrough curve from the test column, either laboratory or pilot scale is required, and the column should be as large as possible to minimize side-wall effects. The scale-up procedure approach for the packed column design is as follows:

1) Use a pilot test column filled with the carbon (adsorbent) to be used in full scale application.

2) Apply a filtration rate and contact time (EBCT) which will be the same for full-scale application (to obtain similar mass transfer characteristics).

3) Obtain the breakthrough curve.

4) Work on the curve for scale-up.

The kinetic approach

This method utilizes the following kinetic equation:

$$
\frac{C}{C_{o}} \cong \frac{1}{1+e \frac{K_{1}}{Q}\left(q_{o} M-C_{o} V\right)}
$$

where $C=$ Effluent solute concentration, $C_{o}=$ Influent solute concentration, $K_{1}=$ rate constant, $q_{o}=$ maximum solid-phase concentration of the sorbed solute, e.g. g/g, $M=$ mass of the adsorbent, e.g., g, $V=$ throughput volume, e.g., litres, $\mathrm{cm}^{3}$ and $Q=$ flow rate e.g., litres/hour, or $\mathrm{m}^{3} / \mathrm{s}$. One advantage of the kinetic approach is that the breakthrough volume, $\mathrm{V}$, may be selected in the design of a column. Assume the left hand side equals the right hand side of Equation (1), cross multiplying gives,

$$
1+e \frac{K_{1}}{Q}\left(q_{0} M-C_{0} V\right)=\frac{C_{o}}{C}
$$

Rearranging and taking the natural logarithms of both sides yield the design equation.

$$
\ln \left(\frac{C_{o}}{C}-1\right)=\frac{K_{1} q_{o} M}{Q}-\frac{K_{1} C_{o} V}{Q} \ldots
$$

A plot of $\ln \left(\frac{C_{o}}{C}-1\right)$ against $V$ will give a slope $\frac{K_{1} C_{o}}{Q}$ from which the design reaction constant, $K_{1}(\mathrm{~L} / \mathrm{s}-\mathrm{kg})$ can be calculated and the design maximum solid-phase concentration, $q_{o},(\mathrm{~kg} / \mathrm{kg})$ calculated from the intercept of Equation (3) [5].

The amount of carbon (adsorbent) required for the design column, (kg) is estimated using Equation (3) by substituting the parameters calculated from the plot of $\ln \left(\frac{C_{o}}{C}-1\right)$ against $V$.

$$
\begin{gathered}
\text { Column height }=\frac{\text { Volume of bed }}{\text { Cross }- \text { sectional area }} \\
\text { Diameter of the column, } d=\sqrt{\frac{4 \times \text { Cross }- \text { sectional Area }}{\pi}} \\
\text { Breakthrough time }=\frac{\text { Volume at breakthrough }}{\text { Volumetric flow rate }}
\end{gathered}
$$

One advantage of column adsorption study is the ability to distinguish the different shapes of the isotherm 
such as linear, convex, or concave. The use of packed column in analyzing non-linear adsorption model isotherms makes it to be more efficient compared to batch adsorption study.

The present work was carried out to evaluate the starch based material potential ability to adsorptively dehydrate ethanol-water mixtures in a fixed bed adsorption column and design a packed bed column from the breakthrough profile parameters generated. For the purpose of this packed column adsorption design, the scale-up approach was used.

\section{Materials and Method}

Analytical grade of ethanol, de-ionized water, $\alpha$-amylase, sodium azide, sodium phosphate, sodium chloride, and sodium hydroxide were purchased from accredited chemical dealers in Onitsha, Anambra State, Nigeria using a scale with an accuracy of $0.01 \mathrm{~g}$.

The method of [6] was used for the enzyme modification of the corn starch. Ethanol-water mixture is prepared at the required mass concentrations of $90 \mathrm{wt} \%$ ethanol.

The fluid phase concentration was measured with the aid of an Abbérefracto meter with automatic calibration in the experimental range of concentration.

\subsection{Design Consideration for Fixed Bed Adsorption Column}

[7] reported column diameters of $30 \mathrm{~mm}, 2.0-2.5 \mathrm{~cm}$ was reported by [4] [8] $5 \mathrm{~cm}$ was reported [9] and $20 \mathrm{~cm}$ by [10] have been employed. To minimize possible wall and axial dispersion effects in fixed columns, it is recommended that the bed length-to-particle diameter ratio be greater than 20 [4]. It could be deduced that the axial dispersion effects could be avoided if the adsorbent particle size is larger by using a deeper column or adsorbent with smaller particle size diameter. The column diameter of $30 \mathrm{~mm}$ and column length of $300 \mathrm{~mm}$ was used for the fabrication of a laboratory scale packed column.

\subsection{Experimental Procedure}

The column study was carried out using a glass column of $30 \mathrm{~cm}$ length and internal diameter $3 \mathrm{~cm}$. The particle size of $600 \mu \mathrm{m}$ was used for the adsorbents. The prepared adsorbent was packed in the column with glass wool layer at the bottom of the bed. Bed height of $90 \mathrm{~mm}$ was used. Peristaltic pump was used to supply the concentration of the ethanol-water mixture (adsorbate) used into the adsorption column at constant flow rate of 6 $\mathrm{ml} / \mathrm{min}, 10 \mathrm{ml} / \mathrm{min}$, and $14 \mathrm{ml} / \mathrm{min}$ while the initial adsorbate concentration used was $90 \mathrm{wt} \%$. The effluent sample was collected at various time intervals and the resulting concentration determined using refractometry method and the earlier obtained calibration curve. The study was terminated when the column exhaustion is reached (Figure 1).

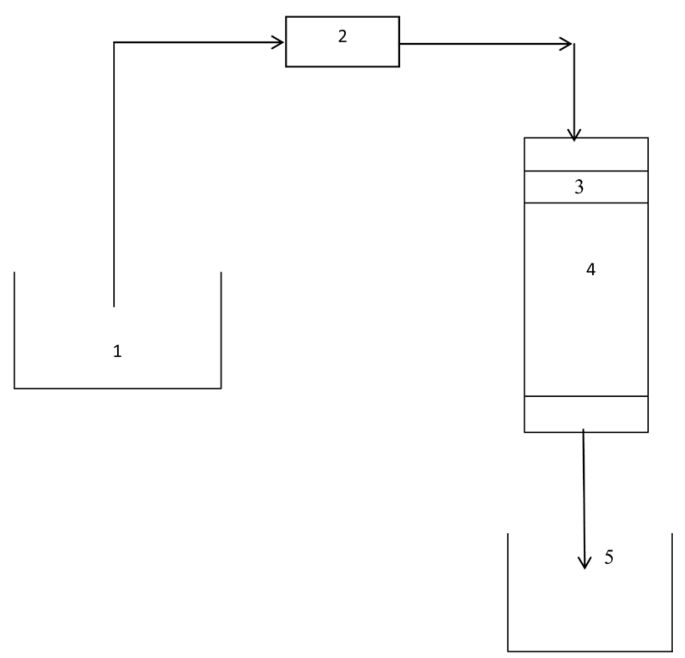

Figure 1. Block diagram of the experimental set-up for column adsorption study. KEY: 1. Influent ethanolwater mixture; 2. Peristaltic Pump; 3. Cotton Wool 5; 4. Glass Column; 5. Sample Collection. 


\section{Results and Discussion}

\subsection{Effect of Flow Rates on Breakthrough Curves}

The effect of flow rate for the sorption of water on to the starch at flow rates of $6 \mathrm{ml} / \mathrm{min}, 10 \mathrm{ml} / \mathrm{min}$, and 14 $\mathrm{ml} / \mathrm{min}$, at an inlet concentration of $90 \mathrm{wt} \%$, and bed height of $90 \mathrm{~mm}$ is shown in Figure 2. It is seen from the figure that the sorption of water is rapid in the initial stages and there was decreased in rate and thereby reaching saturation finally.

This agreed with the results obtained in the works of [11] [12]. It can also be seen from Figure 2 that the breakthrough occurred at a comparatively faster rate at higher adsorbate flow rate and less time was taken to reach the saturation breakthrough. This can be explained from the mass transfer vicinity, the rate of mass transfer gets increased at higher flow rate (the physico-chemical characterization of enzyme modified corn starch is shown in Table 1) leading to faster saturation.

\subsection{Scale-Up Procedure for Packed Column Design}

The laboratory scale pilot test column was used for the full scale design of packed column.

Laboratory scale pilot plant data

Flow rate, $(Q)=6 \mathrm{ml} / \mathrm{min}\left(6 \mathrm{~cm}^{3} / \mathrm{min}\right)$, Column diameter $=30 \mathrm{~mm}(3 \mathrm{~cm})$, Column depth/height $($ Packed bed) $=300 \mathrm{~mm}$, Density of the adsorbent $=1.57 \mathrm{~g} / \mathrm{ml}\left(1.57 \mathrm{~g} / \mathrm{cm}^{3}\right)$, the breakthrough volume from breakthrough curve $=240 \mathrm{ml}\left(240 \mathrm{~cm}^{3}\right)$, and volume at exhaustion $=720 \mathrm{ml}\left(720 \mathrm{~cm}^{3}\right)$.

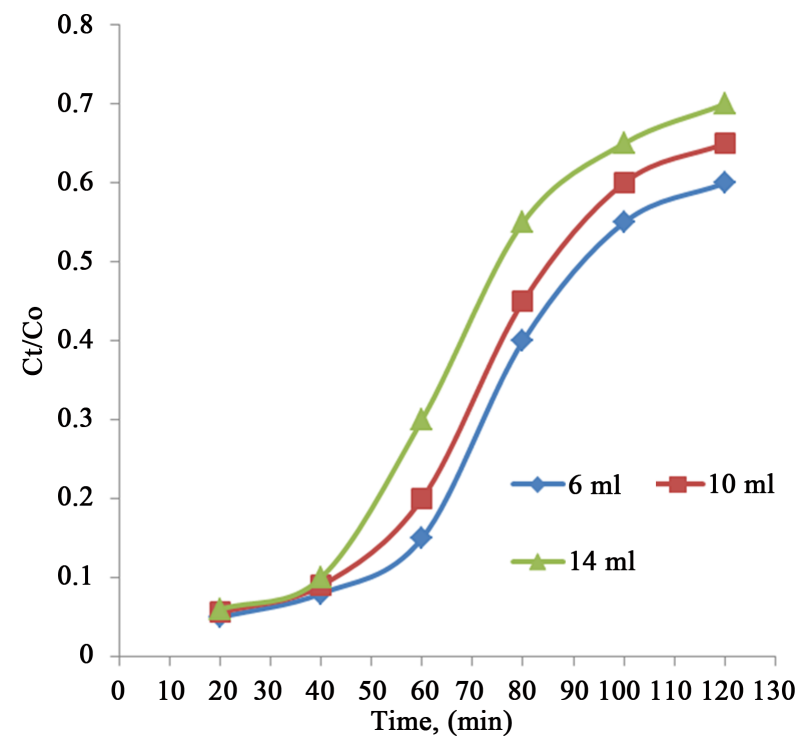

Figure 2. Effect of flow rate on breakthrough curve for adsorption of water on EMCOS.

Table 1. Physico-chemical characterization of enzyme modified corn starch.

\begin{tabular}{cc}
\hline Properties & Modified corn starch (EMCOS) \\
\hline pH & 6.0 \\
Moisture content $(\%)$ & 3.04 \\
Colour & White \\
Starch content $(\%)$ & 86.5 \\
Bulk density $(\mathrm{g} / \mathrm{ml})$ & 1.57 \\
Micro pore volume $\left(\mu \mathrm{m}^{2} / \mathrm{g}\right)$ & 0.2 \\
Diameter $(\mu \mathrm{m})$ & 7.99 \\
Oxygen $(\%)$ & 86.6 \\
Carbon $(\%)$ & 13.4 \\
\hline
\end{tabular}


(A)Filtration rate of the pilot plant

$$
\begin{gathered}
\text { Filtration rate }(F R)=\frac{Q(\text { Flow rate })}{A(\text { cross }- \text { sectional area })} \\
\text { Area }=\frac{\pi d^{2}}{4}=\frac{3.142 \times\left(3^{2}\right)}{4}=7.0695 \mathrm{~cm}^{2}
\end{gathered}
$$

Since flow rate $=6 \mathrm{~cm}^{3} / \mathrm{min}$ and Area $=7.0695 \mathrm{~cm}^{2}$. Therefore; Filtration rate $=0.85 \mathrm{~cm} / \mathrm{min}$. This same filtration rate applies to packed column.

(B) Area of the packed column

$$
\text { Area }=\frac{Q(\text { Flow rate })}{F R(\text { filtration rate })}
$$

If the flow rate of the packed column design is to be $50 \mathrm{~cm}^{3} / \mathrm{min}$.

Therefore; Area $(\mathrm{A})=58.82 \mathrm{~cm}^{2}$. Since Area $=\frac{\pi d^{2}}{4}$ the column diameter, $\mathrm{d}=8.65 \mathrm{~cm}$.

(C) Empty bed contact time of the laboratory scale (EBCT)

$$
\tau(\text { Empty bed contact time })=\frac{\text { Volume of bed }}{Q(\text { flow rate })}
$$

Volume of the bed $=212.085 \mathrm{~cm}^{3}$.

Empty bed contact time $(\tau)=35.35 \mathrm{~min}$. This is the EBCT of the packed column.

(D) Height of the packed column

EBCT $(\tau) \times$ Flow rate $=35.35 \times 0.85=30.05 \mathrm{~cm}$.

This is the same as the height of the laboratory scale pilot plant because height of a column is set by the empty bed contact time $(\tau)$ and filtration rate, and these are the same for laboratory scale pilot plant and the packed column.

(E) Mass of the adsorbent required in the packed column

Volume of the packed column $=$ Cross - sectional area $\times$ Height

$$
\text { Volume of packed column }=\frac{3.142 \times 8.65^{2}}{4} \times 30.05=1766.13 \mathrm{~cm}^{3}
$$

Therefore, Volume $=1766.13 \mathrm{~cm}^{3}(1766.13 \mathrm{ml})$. Packed bed adsorbent density $=1.57 \mathrm{~g} / \mathrm{ml}$

Mass of the adsorbent $=1.57 \times 1766.13=2772.82 \mathrm{~g}(2.77282 \mathrm{~kg})$

(F) Determination of $q_{e}$ (water removed)

Mass of adsorbent in the laboratory scale pilot column $=$ Volume of pilot column $\times$ density of adsorbent $=$ $212.085 \times 1.57=332.97 \mathrm{~g} / \mathrm{g}=0.33 \mathrm{~kg} / \mathrm{kg}$.

Total capacity $=$ Volume at exhaustion $\times$ Time to reach exhaustion $(\mathrm{t})=720 \times 90=64,800 \mathrm{ml}\left(64,800 \mathrm{~cm}^{3}\right)$

Water removed by $332.97 \mathrm{~g}$ of the adsorbent $=$ Total capacity/Mass of the adsorbent in the laboratory scale pilot $=194.6 \mathrm{~g} / \mathrm{g}$.

(G) Fraction of capacity left unused (Laboratory scale)

Total capacity $=720 \times 90=64,800 \mathrm{ml}$

Water removed before breakthrough $=240 \times 90=21,600 \mathrm{ml}$

Fraction of capacity left unused $(f)=(64,800-21,600) / 64,800=0.666=66.7 \%$.

This fraction of capacity left unused will apply to the packed column also.

(H) Breakthrough time of the packed column

Adsorbate loading rate $=90 \times 50=4500 \mathrm{~g} / \mathrm{min}$

Adsorbent consumption rate $=4500 / 194.6=23.12 \mathrm{~g} / \mathrm{min}$

Amount of adsorbent consumed $=2772.82(1-066)=942.76 \mathrm{~g}$.

Breakthrough time $=$ Amount consumed $/$ Adsorbate loading rate $=40.78 \mathrm{~min}$

This is the same as the packed bed column: $240 \mathrm{ml} / 6 \mathrm{mlmin}^{-1}=40 \mathrm{~min}$.

(I) Volume treated before breakthrough 
Volume treated $=$ Flow rate $\times 40.78=2039 \mathrm{~cm}^{3}$.

\section{Conclusion}

The effect of flow rate on the uptake of water on the enzyme modified corn starch adsorbent at flow rates of 6, 10, and $14 \mathrm{ml} / \mathrm{min}$, an inlet concentration of $90 \mathrm{wt} \%$ and bed height of $90 \mathrm{~mm}$ has been studied. The effects of flow rate on the breakthrough curve obtained showed that the adsorptive dehydration efficiency decreased with increasing flow rate. The evaluated parameters from breakthrough curve were used to design a packed column using the scale-up approach. The volume of ethanol-water treated before breakthrough was $2039 \mathrm{~cm}^{3}$. The dehydration of ethanol with this enzyme modified corn starch required less energy compared to distillation that consumes up to $50 \%$ of the overall energy used in a typical grain ethanol plant [13]-[16].

\section{References}

[1] Lin, J.H., Lee. S.Y. and Chang, Y.H. (2003) Effect of Acid-Alcohol Treatment on the Molecular Structure and Physicochemical Properties of Maize and Potato Starches. Carbohydrates Polymers, 53, 475-482. http://dx.doi.org/10.1016/S0144-8617(03)00145-0

[2] Metcalf and Eddy, Inc. (2003) Wastewater Engineering: Treatment and Reuse, 52, McGraw Hill Series in Civil and Environmental Engineering. 4th Edition, McGraw-Hill, New York, 1819.

[3] Eckenfelder, W.W. (2000) Industrial Water Pollution Control. McGraw-Hill Series in Pollution, 138, 358-367.

[4] Zhou, D., Zhang, L., Zhou, J. and Guo, S. (2004) Development of a Fixed-Bed Column with Cellulose/Chitin Beads to Remove Heavy-Metal Ions. Journal of Applied Polymer Science, 94, 684-691. http://dx.doi.org/10.1002/app.20946

[5] Packed Column Design. (2014). http://mimoza.marmara.edu.tr/ zehra.can/ENVE401/5.\%20Adsorption\%20column\%20Design.pdf

[6] Beery, K.E., Gulati, M.K., Eric, P. and Ladisch, M.R. (1998) Effects of Enzyme Modification of Corn Grits and Their Properties as an Adsorbent in a Skarstrom Pressure Swing Cycle Dryer. Adsorption, 4, 321-335. http://dx.doi.org/10.1023/A:1008846003116

[7] Ringquist, L., Holmgren, A. and Öborn, I. (2001) Poorly Humidified Peat as an Adsorbent for Metals in Wastewater. Water Research Journal, 36, 2394-2404.

[8] Gabaldón, C., Marzal, P. and Alvarez-Hornos, F. (2006) Modelling Cd(II) Removal from Aqueous Solutions by Adsorption on a Highly Mineralized Peat, Batch and Fixed-Bed Column Experiments. Journal of Chemical Technology and Biotechnology, 81, 1107-1112. http://dx.doi.org/10.1002/jctb.1425

[9] Sharma, D.C. and Forster, C.F. (1995) Column Studies into the Adsorption of Chromium (VI) Using Sphagnum Moss Peat. Bioresource Technology, 52, 261-267. http://dx.doi.org/10.1016/0960-8524(95)00035-D

[10] Kargi, F. and Pamukoglu, M. (2003) Simultaneous Adsorption and Biological Treatment of Pre-Treated Landfill Leachate by Fed-Batch Operation. Process Biochemistry, 38, 1413-1420. http://dx.doi.org/10.1016/S0032-9592(03)00030-X

[11] Nwabanne, J.T. (2010) Adsorption and Kinetic Modeling of Heavy Metals Uptake from Waste Water Effluents. Ph.D. Dissertation, Nnamdi Azikiwe University, Awka.

[12] Sivakumar, P. and Palanisamy, P.N. (2009) Packed Bed Column Studies for the Removal of Acid Blue 92 and Basic red 29 Using Non-Conventional Adsorbent. Indian Journal of Chemical Technology, 16, 301-307.

[13] Ladisch, M.R. and Dyck, K.K. (1979) Dehydration of Ethanol, New Approach Gives Positive Energy Balance. Science, 205, 898-900. http://dx.doi.org/10.1126/science.205.4409.898

[14] Díaz, J.C., Gil-Chávez, I.D., Giraldo, L. and Moreno-Piraján, J.C. (2010) Separation of Ethanol-Water Mixture Using Type-A Zeolite Molecular Sieves. E-Journal of Chemistry, 7, 483-495. http://dx.doi.org/10.1155/2010/597346

[15] David, M.L., Hammaker, G.S., Buzenberg, R.J. and Wagner, J.P. (1978) Gasohol Economic Feasibility Study. Development Planning and Research Association, Inc., Manhattan.

[16] Benson, T.Y. and George, C.E. (2005) Cellulose Based Adsorbent Materials for the Dehydration of Ethanol Using Thermal Swing Adsorption. Adsorption, 11, 697-701. http://dx.doi.org/10.1007/s10450-005-6009-1 